\title{
EVIDÊNCIAS DE DETERMINAÇÃO MORFOTECTÔNICA E NEOTECTÔNICA NO RELEVO DA SERRA DO MAR NO ESTADO DO PARANÁ
}

\section{MORPHOTECTONIC AND NEOTECTONIC EVIDENCE IN THE SERRA DO MAR RELIEF IN THE STATE OF PARANÁ}

Edenilson Roberto do Nascimento
Universidade Federal do Paraná, Grupo de Pesquisa em Neotectônica. - Rua: Francisco H. dos Santos, 100-Jardim
das américas - CEP 81590-170-Curitiba, PR - Brasil - Telefone: (41) 3361-3691
E-mail: deni_ern@ufprbr
Eduardo Salamuni
Universidade Federal do Paraná. Rua Coronel Francisco Heráclito dos Santos, 100-Centro Politécnico-
Jardim das Américas - CEP 81530-900 - Curitiba, PR - Brasil- Telefone: (41)33613691
E-mail: salamuni@ufprbr

Gustavo Lopes Queiroz Universidade Federal do Paraná. Av Cel Francisco H dos Santos. Centro Politécnico. Bloco 5, sala 9.7. Jardim das Américas - CEP 81531-980 - Curitiba, PR - Brasil-Telefone: (041) 33613691

E-mail: gustavo.lopes.queiroz@gmail.com

Pedro Augusto Hauck da Silva Universidade Federal do Paraná. Av. Cel Francisco H dos Santos, s/n-Centro PolitécnicoCEP 81532-980 - Curitiba, PR - Brasil - Telefone: (41) 33613365

E-mail:falecom@pedrohauck.net

\begin{abstract}
Alberto Pio Fiori
Universidade Federal do Paraná, Setor de Ciências da Terra, Departamento de Geologia. Jardim das Américas Bacacheri-CEP 81531990 - Curitiba, PR - Brasil - Caixa-postal: 19011 - Telefone: (41) 33613128 - Fax: (41) 32662393

E-mail:fiori@ufpr.br
\end{abstract}

Informações sobre o Artigo

Data de Recebimento:

20/02/2013

Data de Aprovação:

03/11/2013

\section{Palavras-chave:}

Morfotectônica; estado do Paraná; morfoestrutural; Serra do Mar.

Keywords:

Morphotectonics, Paraná state; morphostructural; Serra do Mar.

\section{Resumo}

O condicionamento morfotectônico na evolução do relevo da Serra do Mar paranaense foi investigado a partir da análise de parâmetros geomorfométricos, geológicos e geográficos. Em seis áreas com escarpamento associado a grandes lineamentos estruturais, foram verificadas morfoestruturas morfotectonicamente condicionadas. As escarpas estruturais, knickpoints alinhados segundo a direção de importantes estruturas, depósitos aluvionares segmentados por falhas, anomalias de drenagem, remanescentes de paleosuperfícies deformados e bacias suspensas apontaram para evidências que permitem concluir por deformações recentes superimpostas a morfoestruturas mais antigas na formação da paisagem, em especial associadas a estruturas com direções NNESSW e E-W. Essas evidências apontam para a atividade neotectônica na conformação do relevo regional. 


\begin{abstract}
The morphotectonic conditioning over the evolution of the Serra do Mar relief in the State of Paraná was investigated from the analysis of geomorphometric, geologic and geographic parameters. In six areas with escarpment associated to large structural lineaments, morphotectonically conditioned, morphostructures were found. "Structural escarps, knickpoints aligned along the direction of important structures, alluvial deposits segmented by faults, drainage anomalies, deformed palaeosurfaces remnants and suspended basins all point to evidence that allows to conclude by recent deformations superimposed to older morphostructures in the formation of the landscape, mainly associated to structures with NNE-SSW and E-W directions". These evidence points to the neotectonic activity in the conformation of the regional relief.
\end{abstract}

\section{Introdução}

A identificação do controle estrutural das feições geomorfológicas é uma das principais motivações dos estudos morfoestruturais, morfotectônicos e neotectônicos, que apoiados em parâmetros geomorfométricos e geológicos podem fornecer subsídio para o entendimento dos processos formadores do relevo. A interação clima, litotipos, rede de drenagem e a atividade tectônica, que pode ser recente ou relacionada a um ou a uma sucessão de eventos geológicos mais antigos, funciona como um sistema aberto, que pela ação erosiva modela o relevo. A classificação das feições geomórficas constitui um importante e desafiador objeto de estudos das geociências, tarefa que exige o conhecimento do significado geomorfológico, geométrico, cinemático e de idade das estruturas geológicas.

A rede de drenagem, primeiro elemento da paisagem a adaptar-se às deformações tectônicas dos maciços, às mudanças atectônicas no nível de base ou ao controle tectônico do substrato estruturalmente controlado, exposto pela exumação das camadas superiores, figura como o principal componente da paisagem em estudos desta natureza. Dentre as feições anômalas identificáveis na rede de drenagem destacam-se o deslocamento de terraços e inflexões de rios (ROCKWELL et al. 1988), mudanças de direção do fluxo hídrico (HOWARD, 1967; OUCHI, 1985; DEFFONTAINES et al. 1991), vales suspensos, ruptura de perfis de vales, rupturas de perfis de vales de terraços fluviais (SUMMERFIELD, 1991; BISHOP, 1995), vales assimétricos (COX, 1994) e capturas fluviais (BISHOP, 1995), entre outras anomalias de drenagem, que permitem identificar de forma indireta a existência de determinação morfotectônica da paisagem.

Embora diversos autores tenham ressaltado a importância da tectônica para a evolução do relevo da Serra do Mar (ALMEIDA, 1976; MELO et al. 1985; RICCOMINI, 1991; ZALÁN \& OLIVEIRA, 2005 entre outros), as fases de soerguimentos, de colapsos e outros eventos tectônicos, principalmente os relacionados à tectônica recente, foram pouco abordados nos principais estudos realizados na porção paranaense da Serra do Mar (SM). Com exceção de Maack (1972) que em sua concepção admitiu a influência da orogênese dos Andes e suas perturbações de equilíbrio e tensões como responsáveis pela "deficiência e rebaixamento" da orla continental da América do Sul e formação de condições instáveis que promoveram o mergulho no mar de uma superfície pré-terciária ou paleo-terciária (entre o Paleoceno e o Plioceno aproximadamente) formando as baías de Paranaguá e Guaratuba. A identificação e correlação de remanescentes de paleosuperfícies realizada por Ab'Sáber \& Bigarella (1961), e a interpretação de um relevo morfoesculturalmente condicionado, nortearam os principais estudos geomorfológicos na região. Salgado et al. (2013) ao investigar a evolução do relevo na região do entorno da Baía de Antonina, por meio do método de isótopo cosmogênico $\mathrm{Be}$, observou que as taxas desnudacionais de longo-termo no lado oceânico da Serra do Mar é 2,4 vezes mais agressiva do que nas bacias do lado oeste (vertentes continentais). Os dados obtidos pelo autor indicam uma desnudação diferencial entre os granitos (Província Graciosa) e os migmatitos (Complexo Atuba), sendo os litotipos considerados o principal fator controlador das taxas de desnudação de pequenas bacias de drenagem, enquanto, regionalmente, a diferença de nível de base é considerada a principal determinante da diferenciação erosiva entre os litotipos.

As principais motivações do presente trabalho são a busca da confirmação de uma determinação tectônica na evolução recente da SM no Paraná; a inexistência de trabalhos com foco regional apoiados na análise digital do relevo, bem como sua singularidade como unidade de relevo que "representa o núcleo mais importante do setor meridional das escarpas que constituem o alinhamento principal da Serra do Mar no Brasil Sudeste" (AB'SÁBER \& BIGARELLA, 1961 p. 105), e que, segundo Almeida e Carneiro (1998) possui “(...) aspectos notáveis que a diferem dos que se mostra em São Paulo e no Rio de Janeiro".

O objetivo central é a caracterização do relevo da SM paranaense (Figura 1) a partir da análise da influência das estruturas geológicas na paisagem regional, com foco na relação entre a geomorfologia e os principais lineamentos estruturais que determinam o controle morfoestrutural, morfotectônico e/ou neotectônico da paisagem. Os elementos geomorfológicos analisados foram: knickpoints na rede de drenagem, as formações superficiais deformadas, anomalias de drenagem, bacias hidrográficas suspensas e remanescentes geomórficos de paleosuperfícies, os quais serviram para a identificação de atividade tectônica na formação da paisagem da SM. 


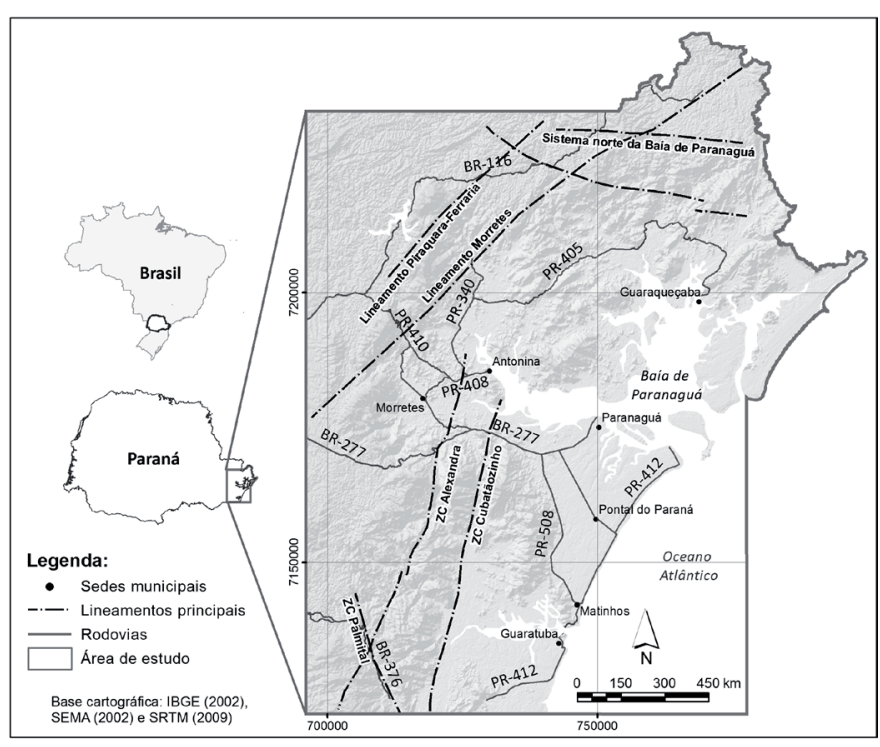

Figura 1 - Localizacao da área de estudo.

\section{Contexto geológico-geomorfológico}

A geomorfologia da SM é caracterizada por um sistema montanhoso com mais de $1200 \mathrm{~km}$ de extensão, que se apresenta do Sul do estado da Bahia até o Sul de Santa Catarina, e possui direção geral nordeste-sudoeste. No Paraná, o conjunto que forma a SM, limita o "primeiro planalto e a planície costeira" (BIGARELLA, 1978) e desenha um "degrau" na forma de escarpa que configura altos topográficos com aspectos orográficos definidos com detalhe por Maack (1972). Os subconjuntos geomórficos são serras marginais denominados de sul para norte de Serra do Piraí, Serra do Iquererim, Serra do Marumbi, Serra dos Órgãos (ou Ibitiraquire), Serra da Virgem Maria, Serra da Igreja, Serra das Canavieiras e Serra do Capivari Grande, além de outras. As serras da Graciosa e da Farinha Seca são consideradas como de feições escarpadas.

Dentre os estudos que abordaram o relevo da SM no Paraná destacam-se Maack $(1942,1947)$ que realizou as primeiras observações sobre a geomorfologia da Serra do Mar e os de Ab'Sáber \& Bigarella (1961) e Bigarella et. al. (1978) que atribuíram aos eventos erosivos no Terciário um importante papel na elaboração das superfícies de aplainamento. Os remanescentes geomórficos das paleosuperfícies, atualmente escalonados na paisagem da SM, foram denominados por Bigarella et. al. (1978) de Pd3 (correlato à superfície Purunã), $\mathrm{Pd} 2$ (correlato à superfície Alto Iguaçu) e Pd1 (equivalente à superfície Curitiba) os quais correspondem respectivamente às Superfície Sulamericana, Velhas e Paraguaçu definidas por King (1956).

A porção montanhosa mais proeminente no estado do Paraná possui altitudes médias entre 1300 e $1800 \mathrm{~m}$, ocorrendo a maior altitude no Pico Paraná (1877m), localizado na Serra do
Ibitiraquire (ou Serra dos Órgãos). Esta é ainda por outros picos com altitudes pouco menores, tais como o Caratuva (1850 m), o Ferraria (1835 m), o Taipabaçu (1817 m) e o Ciririca (1781 m). Entremeados aos morros mais altos há colinas intermontanas, que formam, em geral, superfície pedimentares de altitudes menores entre 300 e $1000 \mathrm{~m}$ (Figura 2).

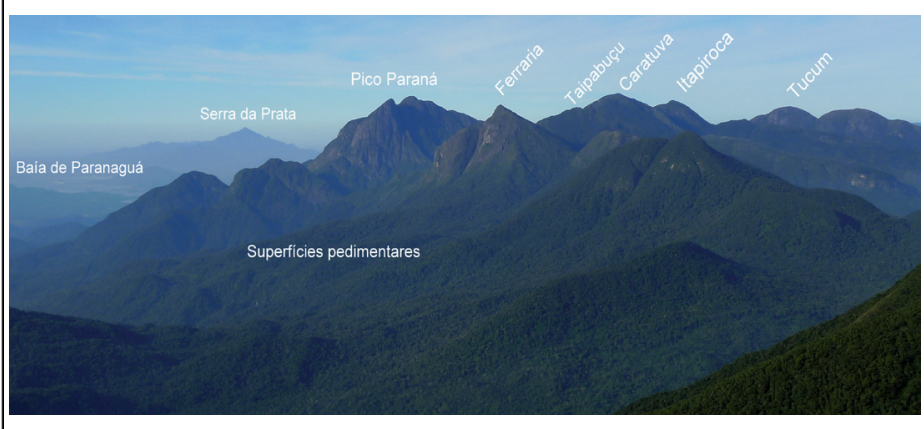

Figura 2 - Vista parcial da Serra do Ibitiraquire - Pico Paraná (1877m), montanha mais alta do sul do Brasil; Pico do Ferraria (1734m), Pico Caratuva (1856m), Pico Itapiroca (1754m), Morro do Tucum (1741m).

Os cerca de $140 \mathrm{~km}$ de extensão e $50 \mathrm{~km}$ de largura da Serra do Mar (SM) paranaense estão, segundo Siga Jr. et.al. (1993, 1995), sob a influência de três grandes segmentos ou domínios geotectônicos que compõem o setor SE paranaense e a porção NE catarinense. Tais domínios foram denominados de Microplaca Luís Alves (BASEI et al, 1992), de Microplaca Curitiba (SIGA JUNIOR, 1995) e de Domínio Costeiro, onde se destaca o Terreno Paranaguá. Os granitos são alcalinos anorogênicos, neoproterozoicos a cambrianos que, por sua resistência a erosão, constituem a barreira que sustenta a borda do Primeiro Planalto Paranaense (PPP).

Cury (2009), em concordância com o modelo proposto por Siga Jr. (1993, 1995) denomina o "Batólito de Paranaguá" de "Terreno Paranaguá", pois considera a presença de diferentes unidades ígneas e metamórficas, destacando-se as Suítes Graníticas Rio do Poço, Canavieira-Estrela, Morro Inglês e a Sequência Rio das Cobras. O Terreno Paranaguá faz parte de um cinturão colisional do Neoproterozoico, com padrão estrutural que indica uma movimentação de SSE para NNE, com cinemática frontal em sua porção setentrional, mas com presença de cavalgamentos e nappismo.

As características peculiares da porção paranaense em relação às demais porções da SM são apontadas por diversos autores principalmente por suas características geológicas. Destaca-se o Cinturão Granitóide, constituído por granitos mais ou menos foliados, granito-gnaisses e migmatitos entre outras rochas (BASEI et al. 1992). A erosão remontante é apontada como responsável pelo recuo do front da Serra do Mar da região de rochas laminadas para a faixa de stocks e batólitos (Figura 3). 


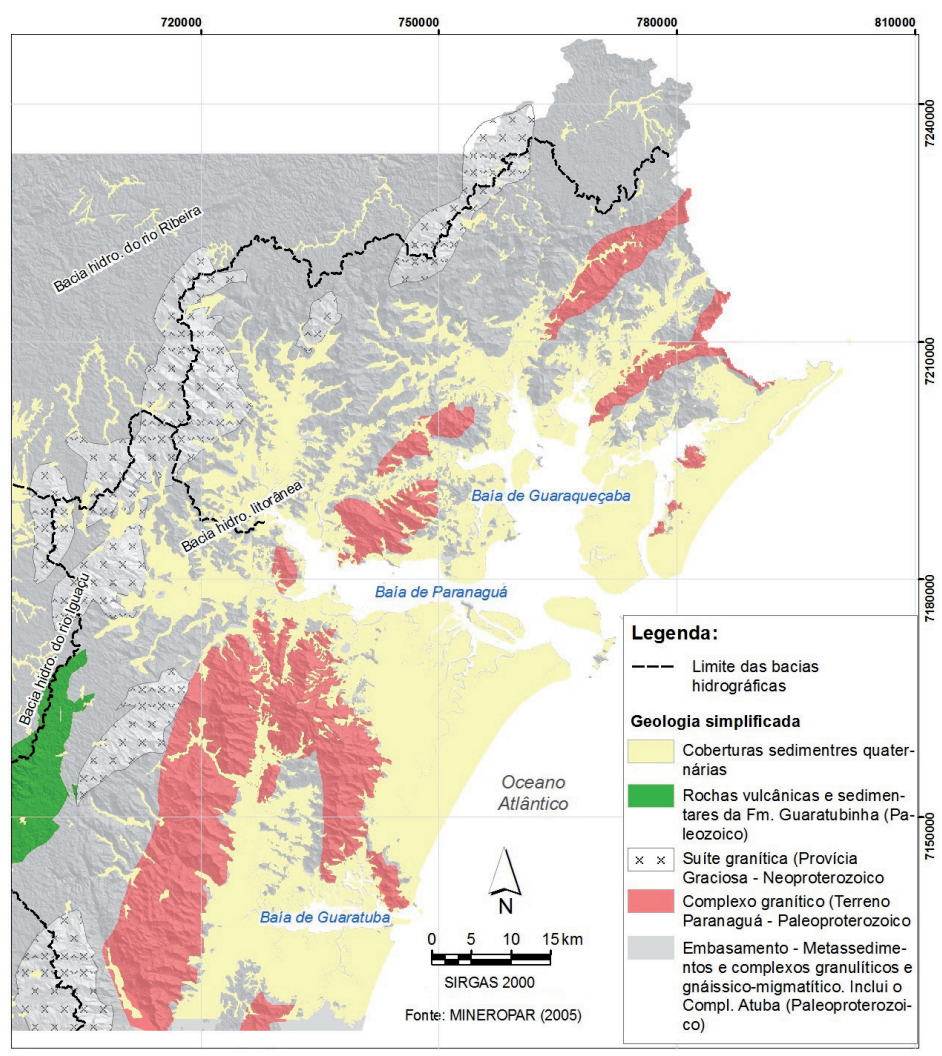

Figura 3-Geologia regional.

A SM paranaense está afetada pelo Arco de Ponta Grossa (APG) de direção NW-SE, sendo balizada a norte pelo alinhamento São Gerônimo-Curiúva e a sul pelo alinhamento Rio Alonzo. A charneira do APG condiciona uma área com grande densidade de diques de diabásio ou rochas aparentadas. As implicações geológicas e geomorfológicas da relação de posição da SM na principal zona de ocorrência do APG possui estreita relação com a evolução geotectônica regional (ALMEIDA, 1967), posto que sua gênese e evolução estão fortemente relacionadas à abertura do Oceano Atlântico (COUTINHO, 2008; ZALÁN et al., 1990, ZALÁN \& OLIVEIRA, 2005 e ASMUS \& GUAZELLI, 1981).

O reconhecimento de pulsos tectônicos em escala continental apoiado no método dos traços de fissão em apatitas e, em evidências geológicas, permitiram Vignol-Lelarge et al. (1994) e Franco-Magalhães et al. (2010) concluírem pela existência de soerguimentos, exumação tectônica e reativação dos alinhamentos estruturais (Guapiara, São Jerônimo-Curiúva, Rio Alonzo e Rio Piqueri) no APG. O resfriamento a partir de 60 Ma no eixo central do APG, é por Franco-Magalhães et al. (2010) considerado um dos principais eventos de reativação de zonas de cisalhamento (ZCs) pré-cambrianas. Nesse contexto, entre o Paleógeno e o Neógeno, os eventos tectônicos somados às variações climáticas regionais deram condições para a elaboração de um relevo montanhoso e estruturalmente condicionado na SM e adjacências. Vale destacar o rifteamento
Cenozoico (ALMEIDA, 1976; MELO et al. 1985; RICCOMINI, 1989, 1991; ZALÁN e OLIVEIRA, 2005), que abrange toda a Serra do Mar, como o evento tectônico de maior expressividade na paisagem atual. Almeida \& Carneiro (1998) realizaram uma revisão do conhecimento sobre as origens da Serra do Mar, dando destaque aos eventos tectônicos e à dissecação e erosão paralela das vertentes que ocorreram no Cenozoico, ao passo que Zalán \& Oliveira (2005) destacam o tectonismo pós Cretáceo. Salamuni (2005) aponta para a influência de possível atividade neotectônica na SM e indica a Zona de Cisalhamento do Cubatãozinho como possível área tectonicamente ativa.

\section{Métodos}

A grande abrangência espacial da área demandou a utilização de dados de várias fontes, destacando-se os altimétricos e hidrográficos, e os dados geológicos disponibilizados pela MINEROPAR (2005) e os dados do projeto TOPODATA (VALERIANO e ROSSETI, 2009), bem como as imagens Landsat ETM7, e as imagens de alta resolução disponibilizadas pelo Google Earth $\bigodot$.

Utilizou-se o levantamento topográfico e o mapa da rede hidrográfica na escala 1: 25.000 (PRÓ-ATLÂNTICA, 2005), tendo sido necessária a inserção de valor de cota altimétrica em cerca de 157.000 curvas de nível e posterior união em um único arquivo. Os dados geológicos e estruturais na escala 1:250.000 fornecidos pela Mineropar foram utilizados como base geológica para a análise realizada.

A partir das imagens raster do projeto TOPODATA com resolução espacial de 30m (VALERIANO e ROSSETI, 2009), derivados dos dados do Projeto SRTM, foram extraídos atributos geomorfométricos (hipsometria, declividade, relevo sombreado entre outros). O tratamento e integração dos dados em ambiente SIG, a confecção do modelo digital de elevação (MDE), foi realizado com a utilização dos softwares do pacote ArcGis 10.

A partir da identificação de estrias e steps foi possível, em alguns planos, determinar os eixos das paleotensões que atuaram nos planos de falhas. Para tanto, foi utilizado o software WinTensor e considerado o método dos diedros retos. Com a análise geométrica das falhas direcionais geradas em ambiente rúptil foi tentativamente relacionada a direção dos vetores de paleotensão identificados (diagramas) aos eventos de deformação descritos em áreas adjacentes (Gráben de Paranaguá, Gráben de Sete Barras, Bacia de Curitiba, Gráben de Paranaguá) e considerados como produto de tectônica recente.

De um total de 174 pontos descritos em várias etapas, foram destacadas as estruturas que se encontram na área de influência dos grandes lineamentos tectônicos, os quais foram analisados nos softwares WinTensor, SIGMAS e Stereo32. 


\section{Knickpoints}

O Stream-Gradient index (SL) proposto por Hack (1973) analisa perfis longitudinais de rios ou de trechos de drenagem a partir do cálculo da declividade do trecho, multiplicada pela distância entre este trecho e a nascente do rio. Tal cálculo define os knickpoints que são de interesse em estudos morfotectônicos, morfoestruturais e neotectônicos. No presente trabalho, para identificar knickpoints, foi utilizado o índice "relação declividade-extensão" (RDE) proposto por Etchebehere et al. (2004), derivado do índice de Hack. O RDE é relativo à energia da corrente em determinado segmento da drenagem, e varia com a declividade da superfície e com a descarga de água no final dele. Este método de análise foi aplicado manualmente, medindo-se as distâncias entre curvas de nível em carta topográfica, por Hack (1973), Etchebehere (2006), Martinez (2011) entre outros. Embora estes estudos tenham obtido sucesso, a análise manual dificulta sua aplicação em áreas extensas, como é o presente caso. Por este motivo foi desenvolvida, no âmbito do grupo de pesquisa em neotectônica da Universidade Federal do Paraná (UFPR), uma rotina eletrônica, programada em linguagem Python, para uso no software Arc GIS. A ferramenta trabalha de maneira similar ao método manual, porém utiliza imagem matricial com dados altimétricos para extrair a rede de drenagem e posteriormente, de forma automática, identificar os knickpoints.

\section{Anomalias de drenagem}

As anomalias de drenagem podem ser definidas como sendo uma feição diferente do padrão regional da rede de drenagem, ou pela existência de trechos atípicos nos canais fluviais que drenam uma bacia hidrográfica. De Blieux (1949) entende o padrão de drenagem esperado como normal, e os seus desvios como anomalias que, para Howard (1967) estariam ligadas a estruturas geológicas. As principais anomalias de drenagem são: drenagem colinear, captura fluvial, desvio de rio, assimetria de bacia, decapitação, retilinidade, inflexão abrupta, diques marginais isolados, curvas anômalas, aparecimento abrupto e localizado de meandros, meandros comprimidos, desenvolvimento abrupto e localizado de canal anastomosado e estreitamento anômalo de vales ou canais.

A partir do trabalho de reconhecimento visual das anomalias de drenagem, objetivando caracterizar os fatores condicionantes da rede de drenagem, foi realizada análise comparativa das mesmas com as feições geomorfológicas e geológicas regionais. A escala de análise ideal para a identificação das anomalias de drenagem na área estudada foi de 1:130.000.

\section{Lineamentos estruturais}

Feições geomórficas como os limites de áreas elevadas ou cristas de cordilheiras, linhas de drenagem, linhas de costa, contatos geológicos e vales alinhados são expressões do relevo comumente associadas a estruturas geológicas como falhas, fraturas, juntas e foliações (SABINS, 1978). O reconhecimento de lineamentos permite a análise das estruturas geológicas que implicam no desenho da morfoestrutura e da morfotectônica, bem como o regime tectônico atuante durante sua formação. Para a análise de lineamentos foram agrupados dados da Comissão da Carta Geológica do Paraná de 1960, interpretações de trabalhos anteriores desenvolvidos na Serra do Mar em projetos coordenados por Eduardo Salamuni (2000; 2005) e interpretações visuais realizadas utilizando modelos digitais de elevação (MDE). A definição dos lineamentos estruturais de interesse neste estudo foi baseada na expressividade regional das escarpas ou escarpas de linha de falhas a eles associados.

\section{Resultados e discussões}

A partir da análise visual e digital dos dados de imagens orbitais, de dados geomorfométricos extraídos de MDEs e de dados geológicos-estruturais obtidos em campo, foram definidos seis domínios principais na SM paranaense com relevo morfoestrutural e/ou morfotectonicamente condicionados. Os critérios de definição desses domínios consideraram a pervasividade regional dos traçados dos lineamentos, a relação do lineamento com as direções dos rios, a existência de escarpamento estrutural e o pré-reconhecimento da estrutura na literatura. Foram identificadas seis sistemas de lineamentos: Sistema norte da Baía de Paranaguá, de influência do lineamento Piraquara-Ferraria, do lineamento Morretes, das Zonas de Cisalhamento Palmital, Cubatãozinho e Alexandra (Figura 4).

A análise dos dados de paleotensão das estruturas rúpteis, por meio do método dos diedros retos, permitiu a definição das principais orientações dos campos de esforços envolvidos nos eventos tectônicos da SM, nas áreas próximas aos seis lineamentos (Figura 5 e Quadro 1). As direções encontradas condizem em muitos casos com os eventos neotectônicos descritos na Bacia Sedimentar de Curitiba (SALAMUNI, 1998), nos grábens de Sete Barras, Cananéia (SOUZA et al. 1996) e Paranaguá (CASTRO et al. 2008) e em áreas estudadas por meio de métodos geofísicos.

Com a análise estatística, por meio de diagramas de rosetas e projeções estereográficas, das atitudes das estruturas (falhas e fraturas), identificadas em campo, foi possível verificar a penetratividade em escala de afloramento das estruturas que definem os principais lineamentos da SM no Paraná (figura 6). Além das direções principais, condizentes em geral com as direções dos escarpamentos estruturais, verifica-se também direções secundárias que controlam morfoestruturas mapeáveis em maior escala. Os padrões de drenagem são determinados por essas estruturas, sendo que $59,3 \%$ da área estudada apresenta padrões de drenagem com forte controle estrutural (Quadro 2). 


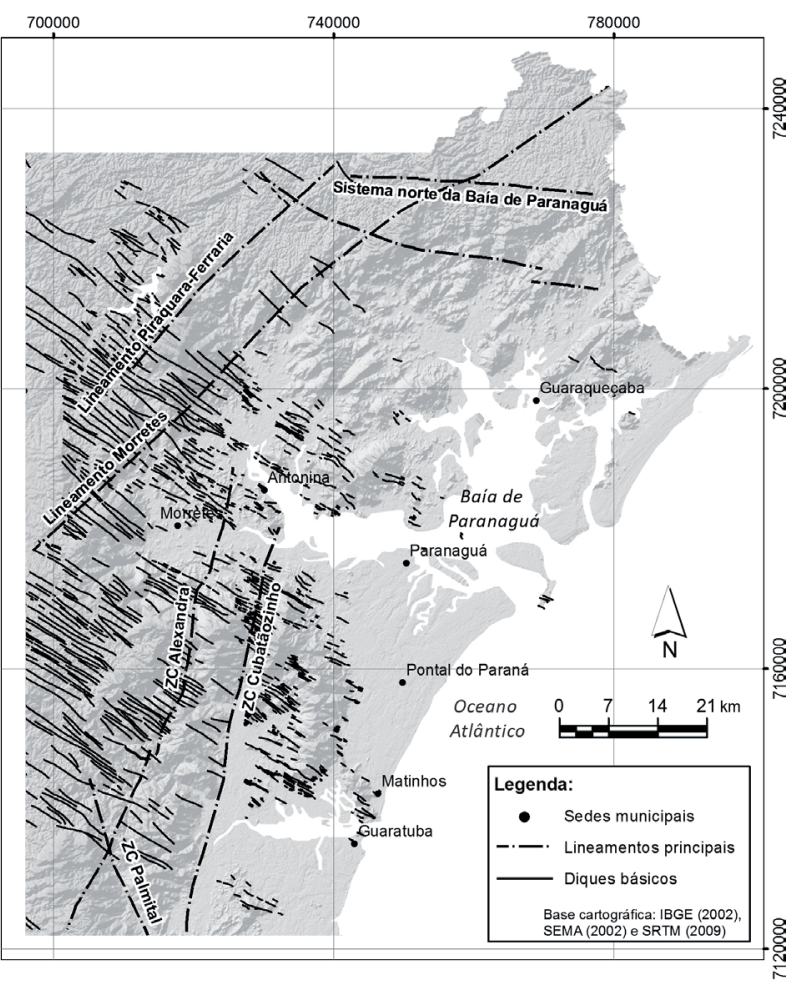

Figura 4 - Lineamentos regionais abordados no estudo e diques de diabásio do $A P G$.

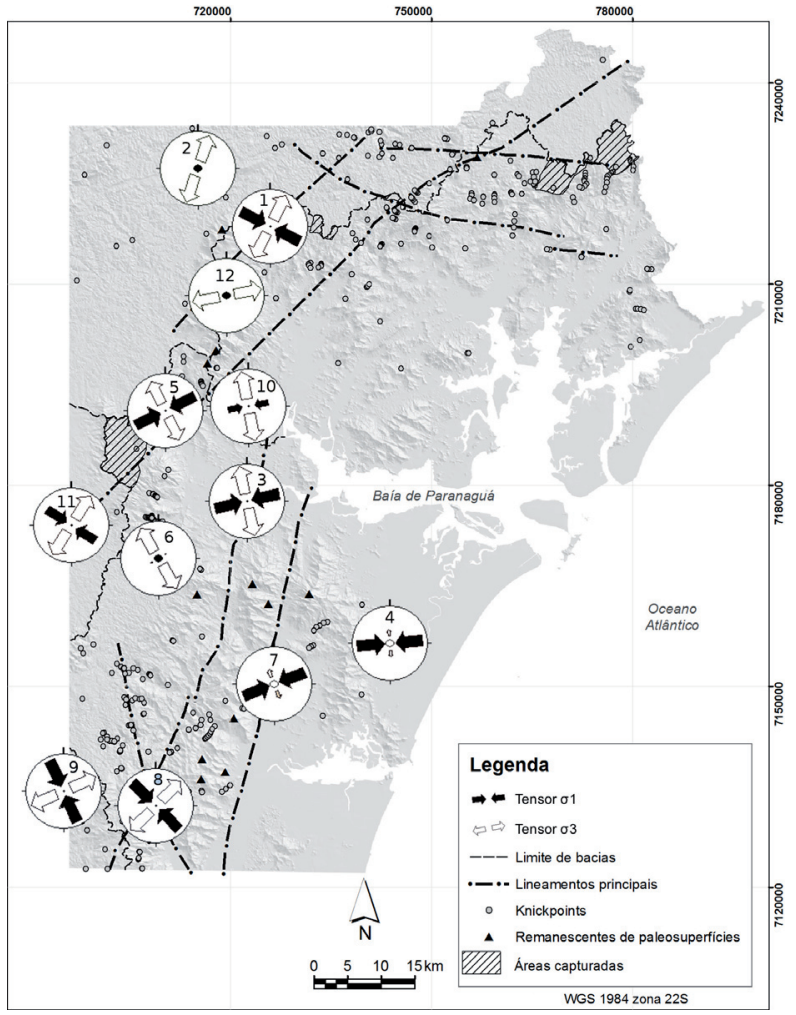

Figura 5 - Indicação da tensão média (paleotensores) das falhas adjacentes aos principais lineamentos estruturais da Serra do Mar (diedros retos). Observar o Quadro 1.

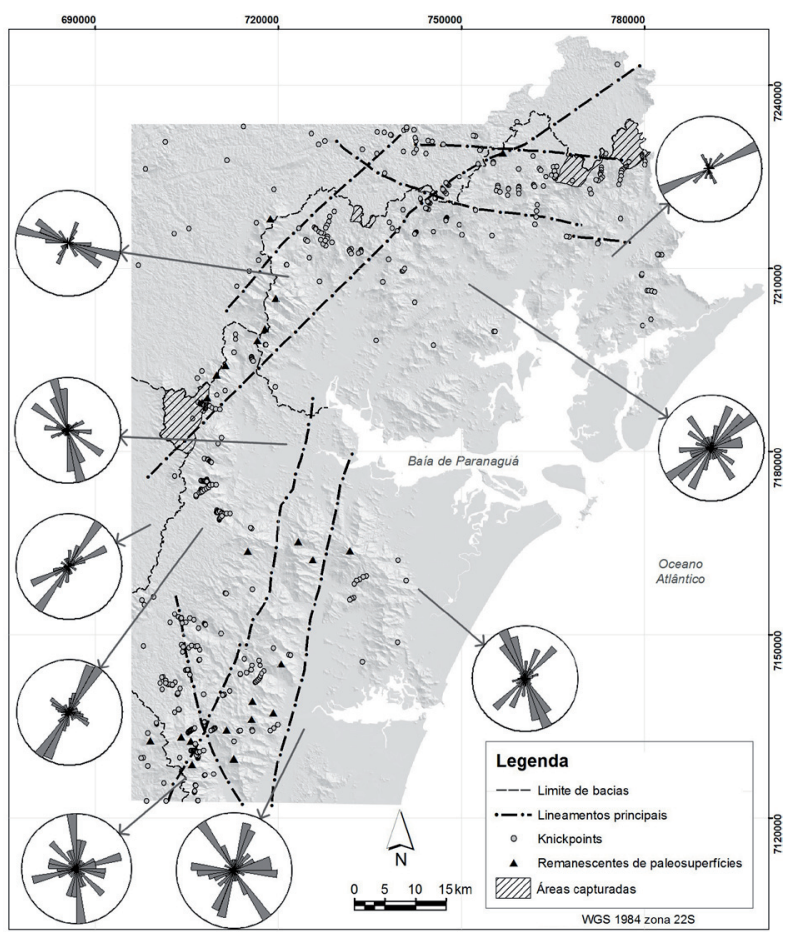

Figura 6 - Lineamentos principais, Knickpoints, remanescentes geomórficos e estereogramas de rosetas das estruturas identificadas em campo.

Quadro 1: Evolução tectônica regional - síntese das paleotensões atuantes no leste do Paraná no Cenozoico segundo Salamuni e Fiori (2012) e Hiruma et al. (2001).

\begin{tabular}{|l|l|l|l|}
\hline $\begin{array}{l}\text { Diagrama de } \\
\text { tensão média }\end{array}$ & $\begin{array}{c}\text { Posição } \\
\text { do eixo } \\
\boldsymbol{\sigma} \mathbf{1} \\
\text { N118/01 }\end{array}$ & $\begin{array}{l}\text { Idade inferida } \\
\text { Quaternária (pós- } \\
\text { pleistoceno }\end{array}$ & $\begin{array}{l}\text { Estruturas típicas } \\
\text { Falha transpressional } \\
\text { dextrógira (falhas } \\
\text { NE-SW) }\end{array}$ \\
\hline 2 & N300/33 & $\begin{array}{l}\text { Tríssico- } \\
\text { Neojurássico }\end{array}$ & $\begin{array}{l}\text { Arco de Ponta } \\
\text { Grossa: falhas } \\
\text { normais e enxame de } \\
\text { diques }\end{array}$ \\
\hline 3 & N253/15 & Neógeno & $\begin{array}{l}\text { Transtração } \\
\text { sinistrógira (falhas } \\
\text { NE-SW) e dextrógiro } \\
\text { (falhas NW-SE) }\end{array}$ \\
\hline 4 & N261/29 & $\begin{array}{l}\text { Quaternária (pós- } \\
\text { pleistoceno }\end{array}$ & $\begin{array}{l}\text { Falha transpressional } \\
\text { dextrógira falhas } \\
\text { NE-SW) }\end{array}$ \\
\hline 5 & N249/58 & Oligoceno & $\begin{array}{l}\text { Négeno } \\
\text { local?) }\end{array}$ \\
\hline 6 & & $\begin{array}{l}\text { Transtração (efeito } \\
\text { sinistrógira (falhas } \\
\text { NE-SW) e dextrógiro }\end{array}$ \\
\hline
\end{tabular}




\begin{tabular}{|c|c|c|c|}
\hline 7 & N068/07 & Neógeno & $\begin{array}{l}\text { Transtração } \\
\text { sinistrógira (falhas } \\
\text { NE-SW) e dextrógiro } \\
\text { (falhas NW-SE) }\end{array}$ \\
\hline 8 & N136/13 & $\begin{array}{l}\text { Paleógeno- } \\
\text { Neógeno }\end{array}$ & $\begin{array}{l}\text { Falha transpressional } \\
\text { dextrógira (falhas } \\
\text { NE-SW) }\end{array}$ \\
\hline 9 & N337/10 & $\begin{array}{l}\text { Paleógeno- } \\
\text { Neógeno }\end{array}$ & $\begin{array}{l}\text { Falha transpressional } \\
\text { dextrógira (falhas } \\
\text { NE-SW) }\end{array}$ \\
\hline 10 & N081/05 & Neógeno & $\begin{array}{l}\text { Transtração } \\
\text { sinistrógira (falhas } \\
\text { NE-SW) e dextrógiro } \\
\text { (falhas NW-SE) }\end{array}$ \\
\hline 11 & N305/05 & $\begin{array}{l}\text { Quaternária (pós- } \\
\text { pleistoceno }\end{array}$ & $\begin{array}{l}\text { Falha transpressional } \\
\text { dextrógira (falhas } \\
\text { NE-SW) }\end{array}$ \\
\hline 12 & N340/33 & $\begin{array}{l}\text { Triássico- } \\
\text { Neojurássico }\end{array}$ & $\begin{array}{l}\text { Arco de Ponta } \\
\text { Grossa: falhas } \\
\text { normais e enxame de } \\
\text { diques }\end{array}$ \\
\hline
\end{tabular}

Quadro2: Percentagem de área de abrangência dos padrões de drenagem identificados na área de estudo.

\begin{tabular}{|c|c|c|c|}
\hline Padrão & $\begin{array}{l}\text { Área } \\
(\%)\end{array}$ & & \\
\hline Subparalelo & 0,5 & & \\
\hline Treliça direcional & 2,6 & $\begin{array}{l}\text { Área total } \\
\text { da SM } \\
(\%)\end{array}$ & Nível de controle \\
\hline Retangular & 2,9 & 59,3 & $\begin{array}{l}\text { Estruturalmente } \\
\text { controlado }\end{array}$ \\
\hline Treliça & 3,1 & 33,9 & $\begin{array}{c}\text { Fraco controle } \\
\text { Estrutural }\end{array}$ \\
\hline $\begin{array}{l}\text { Sem padrão } \\
\text { definido }\end{array}$ & 6,8 & 6,8 & Indefinido \\
\hline Dentrítico & 8,6 & & \\
\hline Paralelo & 11,8 & & \\
\hline Subdentrítico & 25,3 & & \\
\hline Angular & 38,4 & & \\
\hline
\end{tabular}

Foram identificadas 787 anomalias de drenagem na área estudada, concentradas principalmente na porção a norte da Baía de Paranaguá, 521 em um raio de $5 \mathrm{~km}$ da SM ou de seu entorno, localizadas até $1000 \mathrm{~m}$ do divisor de águas da bacia litorânea (Figura 7). Cerca de 333 anomalias de drenagem distam até $100 \mathrm{~m}$ de um lineamento estrutural e 289 distam até $50 \mathrm{~m}$ (lineamentos definidos na escala 1:130.000). A intersecção de diques de direção NW-SE com falhas NE-SW formam as principais inflexões abruptas e vales encaixados quando cortam os maciços graníticos.

As áreas de capturas, onde os rios apresentam um estado de franca reorganização regional a um novo nível de base, rios contorcidos e inflexões abruptas, foram identificadas com maior clareza a leste e a norte da Baía de Paranaguá (Figura 7). Essas áreas abrangem $121 \mathrm{~km}^{2}$ e abrigam pelo menos 29 anomalias de drenagem, destacando-se as inflexões abruptas e as curvas anômalas (Figura 8).

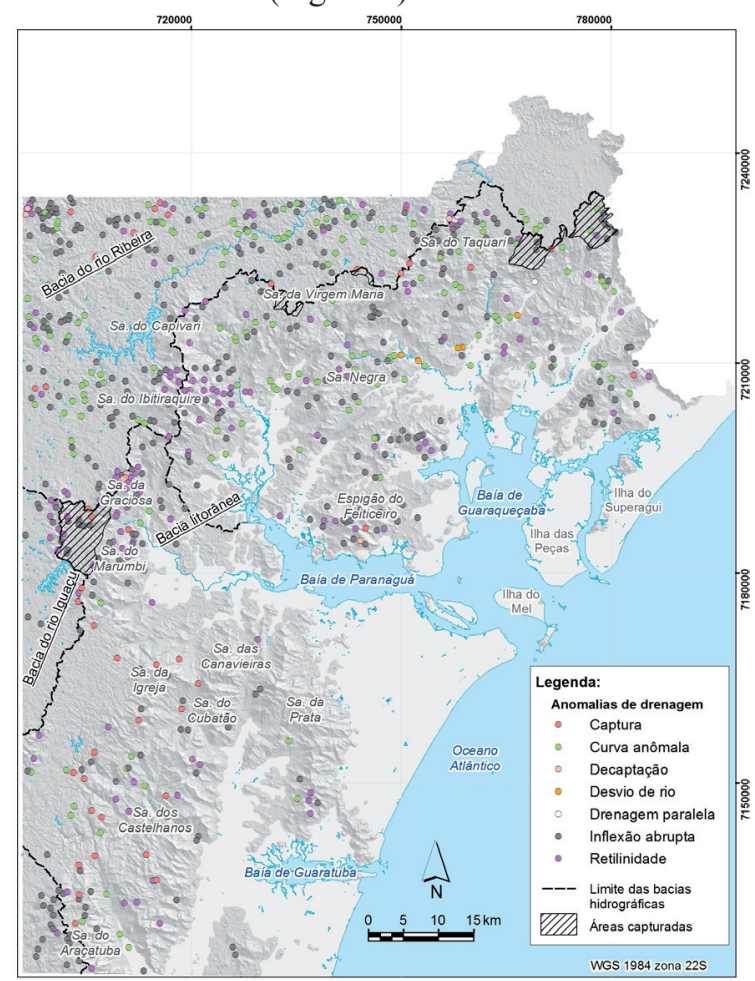

Figura 7 - Anomalias de drenagem identificadas na área de estudo.

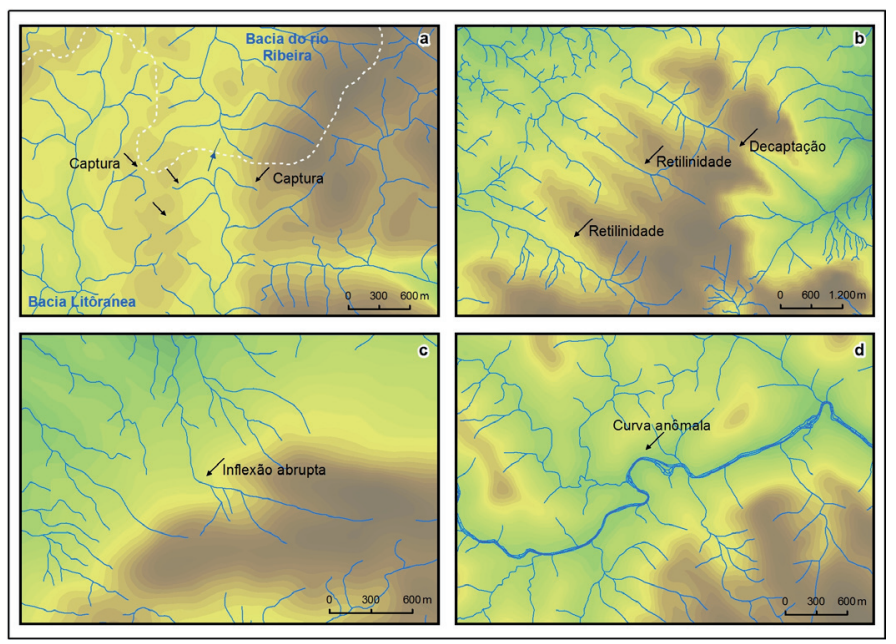

Figura 8-Anomalias de drenagem. a) Captura de drenagem da bacia hidrográfica do rio Ribeira para a bacia litorânea (cood. central: $x=705374, y=7189011)$; b) Retilinidade anômala $e$ decapitação de rios na Serra do Ibitiraquire (coord. central: $x=$ $717815, y=7207665)$; c) Inflexão abrupta na Serra da Igreja (coord. central: $x=712874, y=7166311)$; d) Curva anômala na Serra dos Castelhanos (coord. central: $x=712224, y=7143437$ ). 


\section{Norte da Baía de Paranaguá}

Os lineamentos ocorrentes a norte da Baía de Paranaguá, principalmente na região NE da área de estudo, não são definidos por uma escarpa de linha de falha, mais sim por uma série de escarpas determinadas por estruturas geológicas que cortam as serras da Virgem Maria, de Serra Negra e do Taquari, e condicionam importantes morfoestruturas, especialmente na região de serra que limita a região litorânea e o Primeiro Planalto Paranaense (PPP). Os diagramas 5 e 11 (Figura 5 e Quadro 1) apontam dois eventos de deformação atuantes na região deste lineamento, o primeiro no Neógeno caracterizado por transtração sinistrógira e o segundo processado no Quaternário com transpressão dextrógira. Há duas direções principais, NNE que define a direção dos rios principais e EW onde se verifica escarpas e knickpoints na rede drenagem (Figura 4). Os rios que deságuam na Baía de Paranaguá são alinhados segundo a direção de grandes lineamentos de direção geral NNE e apresentam extensas planícies aluvionares que adentram até a sopé da SM. Desde a porção norte da Baía de Paranaguá (exutório), até as cabeceiras dos rios em áreas geralmente recém capturadas da bacia do rio Ribeira no PPP, há diversas anomalias de drenagem, destacando-se as inflexões abruptas e as curvas anômalas.

Embora haja uma profusão de lineamentos, destacamse os lineamentos de direção próxima E-W tanto em extensão quanto na densidade regional. Essas direções são identificadas em campo como falhas transcorrentes dextrais. A zona de influência dos lineamentos (WNW-ESE) apresentam importantes características morfotectônicas, algumas delas com indícios de atividade neotectônicas. Na região do Salto Morato (Município de Guaraqueçaba-PR), um dos principais knickpoints regionais, a escarpa de linha de falha da cachoeira apresenta facetas triangulares, depósito aluvionar descontínuo (limitado pela escarpa - deposição a montante e a jusante do salto). A pequena bacia hidrográfica drenada a montante do salto possui curvas anômalas e canais fluviais defluentes que caracterizam uma rede de drenagem em fase de adaptação.

Em praticamente toda a região há diversos knickpoints próximos a defluências de drenagem e anomalias controladas por lineamentos de direção próxima N80W (mesma direção do lineamento do Salto Morato). Na bacia do rio Pederneiras, por exemplo, ocorrem diversas nascentes localizadas sobre depósitos aluvionares de idade quartenário/holoceno (MINEROPAR, 2005), além de depósitos segmentados por knickpoints que formam cachoeiras com dezenas de metros, controladas por lineamentos $\mathrm{N} 75-85 \mathrm{~W}$, que permitem inferir um controle acentuado de deformações quaternárias em praticamente toda a região. Há frequentemente, escalonamentos em degrau de planícies aluvionares (de idade quartenário/ holoceno), separadas por knickpoints, ao longo dos rios, tanto em posições a poucos metros do nível do mar, próximo a baía de Paranaguá, quanto em áreas de capturas recentes no PPP
(Figura 9A e 9B). A sobreposição de padrões de drenagem e a predominância de padrões angulares e subparalelos indicam também um acentuado controle estrutural da rede de drenagem da região.

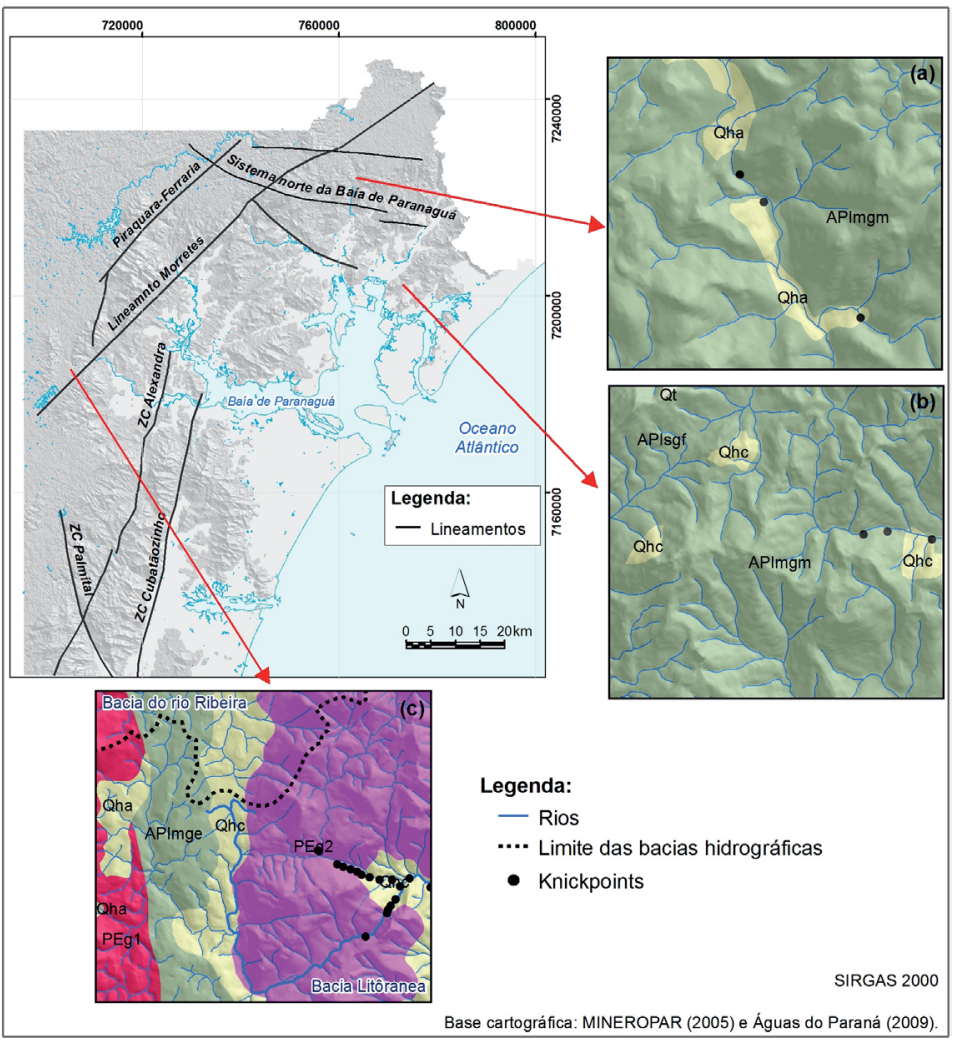

Figura 9 - Localização de feições neotectônicas. (a) knickpoint segmentando depósitos fluviais; (b) rios com nascente sobre depósito quaternário; (c) rio Ipiranga (rio destacado) cortando depósito coluvionar de mesma idade nas duas vertentes do corpo granítico. Qha-Sedimentos fluviais(Quaternário/Holocêno); Qt - (Quaternário/ Holocêno); C - Depósitos de colúvios (Terciário/Quaternário); PEg1 e PEg2 - Suítes álcali-granitos (Proterozóico Superior); APImge Complexo Atuba (Arqueano - Proterozoico Inferior).

\section{Lineamento Piraquara-Ferraria}

O lineamento Piraquara-Ferraria ocorre entre as Serras do Ibitiraquire, do Capivari e da Virgem Maria, e constitui o principal balizamento do front montanhoso da porção extremo noroeste da SM (Figura 4). Seu plano de direção NE-SW possivelmente foi reativado como falha transpressional dextrógira no Quaternário (Diagrama 1 da Figura 5 e Quadro 1). Entre este lineamento e o lineamento Morretes localizam-se uma das principais concentrações de knickpoints e feições anômalas na rede de drenagem. Os rios encaixados nesse lineamento passam a ter seus cursos segundo a direção NE e/ou a assumir feições anômalas (curvas anômalas ou inflexões abruptas) tanto no substrato granítico quanto nos litotipos do Complexo Atuba. $\mathrm{O}$ padrão de drenagem angular e retangular predominam na 
área granítica, e são fortemente influenciados pela direção dos diques e das estruturas paralelas ao lineamento PiraquaraFerraria. Além de quatro knickpoints sobre o lineamento, alinhados na direção exata do front montanhoso, observa-se o balizamento de um grande depósito coluvionar a leste do Morro do Guaricana por este lineamento, o que sugere um condicionamento morfotectônico recente, corroborando para a existência de atividade neotectônica em sua área de influência.

\section{Lineamento Morretes}

O Lineamento Morretes possui mais de $100 \mathrm{~km}$ de comprimento (Figura 4) e diferentes características geológicas e geomorfológicas ao longo de seu traçado, predominando em sua porção mais a sudoeste, na região da Serra do Marumbi e da Graciosa, uma grande área recém capturada da bacia do Alto Iguaçu, com canais fluviais anômalos e ocorrência de knickpoints (Figura 9c). Os knickpoints ocorrem sobre os sedimentos coluvionares recentes e sobre o granito Graciosa. Nas cabeceiras da área capturada há a presença de pelo menos dois pontos de captura atual. Os sedimentos quaternários/holocênicos são cortados pelo rio Ipiranga com direção não concordante com sua deposição gravitacional (o rio corta o colúvio e o rejuvenesce). Já em outra porção do mesmo depósito, drenada pelo rio Ribeira, encontram-se as nascentes do rio Capivari Mirim (Figura 9c). Na vertente litorânea se destaca o truncamento dos depósitos de mesma idade, também pelo rio Ipiranga, em direção concordante com o seu depósito gravitacional, ou seja, depósitos de mesma idade são cortados pelo rio nas duas vertentes do bloco montanhoso. Este fato sugere a captura recente (pós deposição quaternário/holocênica) e rejuvenescimento do depósito e exumação da superfície subjacente. Em geral, os knickpoints situam-se próximos ao lineamento Morretes, e possuem direção perpendicular ao mesmo, coincidindo com a direção dos diques. A zona de balizamento tectônico de unidades geológicas limita porções com diferentes padrões de drenagem, havendo predomínio do padrão angular e retangular em forma de candelabros na área de ocorrência de granitos e sub-dentríticos nas porções mais rebaixadas sobre o Complexo Atuba. Aliada à determinação estrutural, a ação erosiva intensa, mensurada por Salgado et al. (2013), permite um avanço erosivo intenso dos rios da bacia Litorânea sobre o PPP. Nota-se a presença de diversos remanescentes de paleosuperfícies (Figura 10) com rede de drenagem anômala e grandes knickpoints (com centenas de metros), separando a rede de drenagem dos remanescentes e do sistema de drenagem regional. Na região da serra do Ibitiraquire, conforme observa-se na Figura 11A, observa-se o grande front da SM visto a partir do Pico Paraná, e a existência de estruturas N35$45 \mathrm{E}$, deformadas por um evento possivelmente transtrativo, que determinam uma série de planos escalonados na vertente leste do Pico Ferraria (Figura 11B).
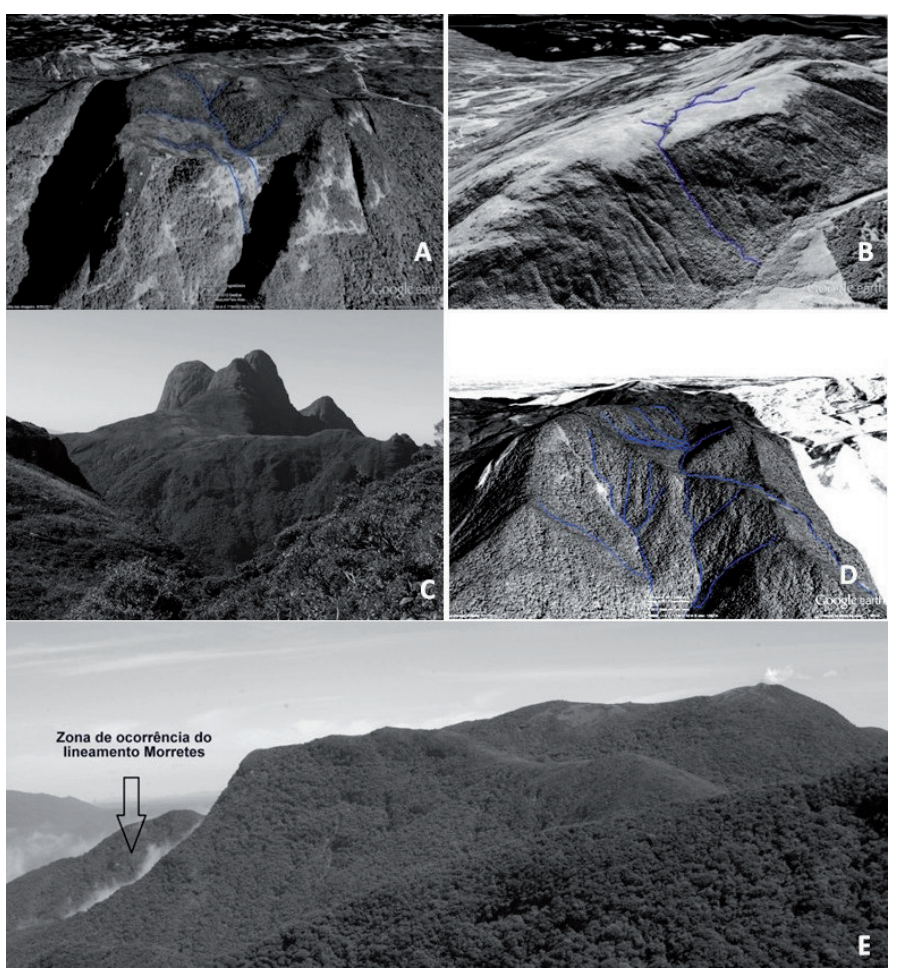

Figura 10 - A - Morro do Sete 1250 m de altitude. Remanescente do Pd3 descrito originalmente por Bigarella et al.,1978 (imagem Google Earth(C); B - Remanescente geomórfico do Pd3 na Serra do Araçatuba à $1440 m$ de altitude (imagem Google Earth(C); $C$ - Remanescente geomórfico do Pd3 na Serra do Ibitiraquire à $1600 m$ de altitude (Pico Paraná); D - Remanescente geomórfico do Pd3 na Serra do Araçatuba à $1250 m$ (imagem Google Earth ()); E - Remanescente do pediplano Pd3 (Superficie Sulamericana), Morro do Tapapui a $1380 \mathrm{~m}$ de altitude.

A porção central da Serra da Graciosa apresenta knickpoints mais recuados em relação ao lineamento Morretes, com drenagem mais controlada segundo as direções dos diques. Nesta área a extensão maior do corpo granítico funciona como uma barreira mais eficiente em relação ao recuo erosivo dos rios em direção ao PPP. Os lineamentos NE, paralelos ao Lineamento Morretes, na área central do corpo granítico são as áreas de ocorrência dos rios de primeira e segunda ordem, enquanto nas bordas do corpo, os rios aproveitam as estruturas NE de forma mais acentuada, com rios de ordem maior sobre a suíte granítica. Os afluentes do rio Cachoeira, na região da serra do Ibitiraquire, apresentam concentrações de knickpoints, em especial os rios com características que apontam para uma recente captura da bacia do rio Ribeira para a bacia litorânea. A concentração de knickpoints sobre as estruturas NE e NW indicam uma acentuada determinação morfotectônica no relevo regional, sendo identificada a existência de sobreposição dos padrão de drenagem subdentrítico e angular, fato que aponta para o ajustamento da rede de drenagem. 

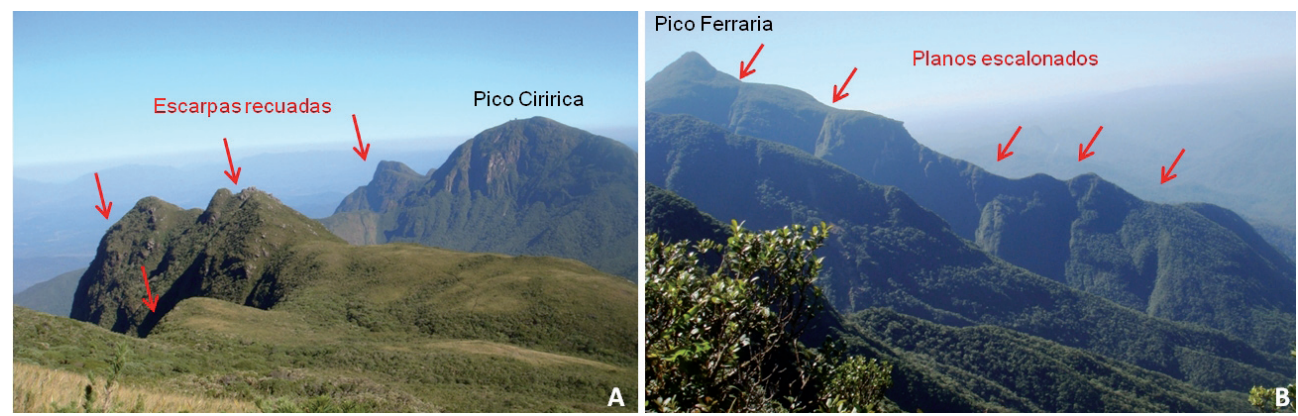

Figura 11 - A) Front da Serra do Mar (Serra do Ibitiraquire). B) Planos escalonados (Pico Ferraria).

\section{Zona de Cisalhamento do Palmital}

É uma das principais falhas da porção sul da área de estudo e marca o balizamento do Terreno Paranaguá com as microplacas Luiz Alves e Curitiba (zona transcorrente sinistral), e condiciona a direção dos rios desde a baía da Babitonga-SC até o Primeiro Planalto Paranaense (PPP), com expressão geomorfológica desde a cota $0 \mathrm{~m}$ até aproximadamente a cota $800 \mathrm{~m}$ de altitude (Figura 4). A região centro-norte e norte da $\mathrm{ZC}$ é drenada por rios pertencentes à bacia litorânea que aproveitam as descontinuidades estruturais e transpõem as serras do Araçatuba, dos Castelhanos, da Igreja, do Cubatão, das Canavieiras em direção ao PPP até alcançarem a Bacia Sedimentar de Tijucas, onde verifica-se uma série de anomalias de drenagem e divisores de águas tênues (estágio embrionário) entre a bacia litorânea e do rio Iguaçu. Os knickpoints estão localizados predominantemente em áreas próximas à $\mathrm{ZC}$, alinhados segundo a direção N40-45W concordante com a direção dos rios principais, e também alinhados segundo a direção N15W da ZC Palmital. A área central e sul do lineamento apresenta feições geomorfológicas típicas de zonas tectonicamente condicionadas, com feições morfotectônicas e morfoestruturais características de zonas de falhas (facetas triangulares, escarpamento estrutural e rios com anomalias de drenagem). O nível de base local é determinado pela ZC, rio São João, a partir do qual rios de ordem menor, encaixados nas falhas N70E drenam as porções mais altas das serras adjacentes. As áreas mais altas das serras apresentam diversas bacias hidrográficas suspensas (remanescentes de paleosuperfícies), conectadas à rede hidrográfica por canais com knickpoints orientados N70E com diversas capturas de drenagem (Figura 12). Os indicadores cinemáticos indicam a tensão principal NW-SE e NNW-SSE oriundas de regime transcorrente concordante com direções consideradas como reativações cenozoicas (CASTRO et al. 2008; SOUZA et al. 1996).

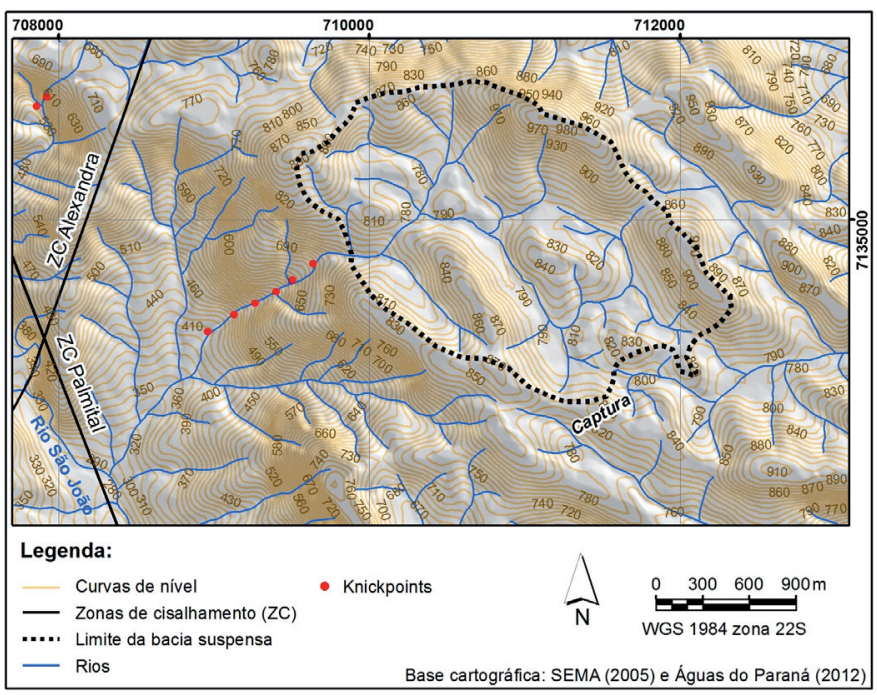

Figura 12 - Bacia de drenagem em remanescente de paleosuperficie com altitude média de aproximadamente $800 \mathrm{~m}$. Reparar o fato de a rede de drenagem apresentar padrão anômalo, provavelmente capturado, e a bacia hidrográfica ser conectada à rede de drenagem principal (alinhado segundo a ZC Palmital) por rio repleto de Knickpoints.

\section{Zonas de Cisalhamento Alexandra e Cubatãozinho}

As zonas de cisalhamento Alexandra e Cubatãozinho determinam os dois principais lineamentos estruturais a sul da Baía de Paranaguá e possuem direção próxima N15E e cortam as serras da Igreja, do Cubatão dos Castelhanos, das Canavieiras, e da Prata. Assim como a ZC Palmital estas duas zonas de cisalhamento marcam o balizamento tectônico do Terreno Paranaguá com as microplacas Luiz Alves e Curitiba (Figura 4). Os diagramas de paleotensão 3 e 7 (Figura 5 e Quadro 1) indicam que movimentos como falhas transtrassionais sinistrógiras ocorreram nas duas ZCs provavelmente no Neógeno, sendo encontradas na região norte destes lineamentos, desde a baía de Paranaguá até a região de serra nos divisores de águas com os rios que drenam para a Baía de Guaratuba, capturas de drenagem incipientes e poucas anomalias de drenagem. Nesta região os rios têm 
seus cursos principalmente sobre áreas com altimetria de até $50 \mathrm{~m}$ de altitude, sendo as porções de serras drenadas por trechos curtos com declividade acentuada. Destacamse as extensas planícies aluvionares entulhadas de material detrítico de proporções até decamétricas, preenchidas em eventos rápidos de fluxo de massa (a exemplo do ocorrido em março de 2011).

A ZC do Cubatãozinho apresenta a sul da Serra das Canavieiras o escarpamento estrutural melhor definido da Serra do Mar paranaense, que delimita a ampla planície do rio Cubatãozinho formada por sedimentos aluvionares e paleoestuarinos do conjunto montanhoso da SM. Os rios da margem direita do rio Cubatãozinho apresentam extensão de até $60 \mathrm{~km}$ e chegam a drenar áreas do PPP. Os rios com ordem inferior a três, entre as ZCs do Palmital e Alexandra, possuem direções fortemente influenciadas pela direção $\mathrm{N} 45 \mathrm{~W}$ dos diques, e os rios de ordem maior apresentam direções determinadas por grandes lineamentos estruturais de direção próxima N70E e N60W que controlam suas direções e as deposições aluvionares. As anomalias de drenagem do tipo inflexão abrupta, curva anômala e retilinidade são verificadas principalmente na região a oeste da ZC Alexandra, onde extensas e estreitas planícies aluviais são limitadas por esta ZC (contato litológico do embasamento com o granito Canavieiras estrela), e a leste pela ZC do Palmital. A direção, a densidade e o padrão de drenagem verificado nas zonas de influência das ZCs possuem diferentes características quando sobre os granitos e os litotipos do Complexo Atuba, predominando direções mais controladas pela direção dos diques, rede de drenagem menos densa e padrão de drenagem angular sobre os granitos, e rios com direções mais variadas e maior densidade de drenagem sobre o Complexo. A concentração de knickpoints a oeste da Baía de Guaratuba, na área de ocorrência de granitos e de embasamento, estão em geral sobre rios de direção N45$65 \mathrm{~W}$ paralelos aos diques e sobre os linemantos N35-45E que cortam os diques de diabásio. Os knickpoints nas regiões mais próximas da ZC Cubatãozinho, a leste da ZC Alexandra, ocorrem sobre os granitos em vales sem preenchimento sedimentar comumente sobre a rocha, enquanto a oeste da ZC Alexandra os Knickpoints ocorrem também nos depósitos sedimentares. As bacias suspensas e os remanescentes geomórficos da paleosuperfície Sul-americana possuem a maior concentração entre as ZCs Alexandra e Cubatãozinho em áreas normalmente com drenagem anômalas, próximas a knickpoints e capturas recentes.

\section{Conclusões}

Há seis lineamentos estruturais que determinam os principais traços do relevo da SM paranaense, e portanto, o relevo regional é morfotectonicamente condicionado. Foram identificadas diversas evidências neotectônicas na paisagem que apontam a ação da tectônica recente, tais como: escarpas estruturais, knickpoints alinhados segundo a direção de importantes estruturas, depósitos aluvionares segmentados por knickpoints, anomalias de drenagem e bacias suspensas, elementos da paisagem que permitem concluir por deformações recentes na formação da paisagem da Serra do Mar, que por fim tem sido esculpida pela ação dos agentes climáticos em curtos ciclos temporais.

As direções NNE-SSW e E-W são as principais direções de estruturas que contém feições tectônicas que determinam morfoestruturas. Os lineamentos NNE-SSW provavelmente possuem relação com a tectônica distensiva cenozoica formadora do sistema de riftes da Serra do Mar (ALMEIDA, 1976) ou "Riftes Continental do Sudeste do Brasil" (RICCOMINI, 1989), que reativou falhas pré-cambrianas que balizam o Terreno Paranaguá com as microplacas Curitiba e Luis Alves. As direções E-W, em especial as transcorrências dextrais e as falhas normais são correlacionáveis a fases neotectônicas e a reativações de estruturas preexistentes no pleistoceno (SILVA \& MELLO, 2007), bem como as direções NW-SW comprovadamente reativadas no Gráben de Paranaguá (CASTRO et al. 2008).

No que concerne à existência de atividade tectônica recente na formação da paisagem, pode-se destacar também a existência de knickpoints entre depósitos sedimentares segmentados, e diversas nascentes de rios em áreas anteriormente ocupadas por planícies aluvionares a norte da Baía de Paranaguá, balizamento tectônico de depósitos aluvionares relacionados ao lineamento Piraquara-Ferraria, além de remanescentes geomórficos e anomalias de drenagem na área de influencia dos lineamentos Alexandra, Cubatãozinho e Palmital.

Todos estes fatores estruturais observados influenciam na dinâmica evolutiva do relevo ainda em curso, com capturas de drenagem para as bacias litorâneas que aceleram a erosão remontante, dissecando a Serra do Mar e entalhando grandes vales que ressaltam as montanhas, dando a peculiar característica de cadeia montanhosa que distingue a SM do Paraná da de São Paulo. A localização dos knickpoints na rede de drenagem em conjunto com a análise dos lineamentos estruturais, dados de paleotensão, geomorfométricos e trabalhos de campo mostrou-se importante na caracterização morfotectônica e da tectônica recente na esculturação do relevo.

\section{Agradecimentos}

Ao Projeto Falhas - Convênio UFPR/PETROBRAS pelo financiamento da pesquisa entre os anos de 2009 e 2011. Ao Programa de Pós-graduação em Geologia da Universidade Federal do Paraná (UFPR). E a CAPES pelo apoio financeiro. 


\section{Referências bibliográficas}

AB'SABER, A. N.; BIGARELLA, J. J. Considerações sobre a geomorfogênese da Serra do Mar no Paraná. Boletim Paranaense de Geografia, Curitiba, v. 4/5, p. 94-110. 1961.

ASMUS, H. E.; GUAZELLI, W. Sumário das estruturas da margem continental brasileira e das áreas continentais e oceânicas adjacentes. Hipóteses sobre o tectonismo causativo e implicações no prognóstico de seu potencial em recursos minerais. Série Projeto REMAC nº 9, 1981. p. 187 - 269.

ALMEIDA, F. F. M. Origem e evolução da Plataforma Brasileira. DNPM, Bol. Div. Geol. Rio de Janeiro. n. 241, p. 1-36. 1967.

ALMEIDA, F. F. M. The system of Continental Rift bordering the Santos Basin, Brazil. Anais. Academia. Brasileira. Ciências, 48 (supl.), p. 15-26. 1976.

ALMEIDA, F. F. M.; CARNEIRO, C.D.R. Origem e evolução da Serra do Mar. Revista Brasileira de Geociências, v. 28, n. 2, p. 135-150. 1998.

BAHNIUK, J. ; SALAMUNI, E. ; GALLINA, F. ; PORTELA FILHO, C. V. . Análise da tectônica rúptil, paleotensões e estudos neotectônicos na Serra do Mar no Estado do Paraná . In: 41 Congresso Brasileiro de Geologia, 2002, João Pessoa, 2002.

BASEI, M. A. S.; SIGA JUNIOR, O.; MACHIAVELLI, A.; MANCINI, F. Evolução tectônica dos terrenos entre os Cinturões Ribeira e Dom Feliciano (PR - SC). Revista Brasileira de Geociências, v. 22, n. 2, p. 216-221. 1992.

BIGARELLA, J. J; BECKER, R.D; MATOS, D.J de; WERNER, A. (Ed). A Serra do Mar e a porção oriental do Estado do Paraná: Um problema de segurança ambiental e nacional. Secretaria do Estado do Planejamento do Paraná. Curitiba. 249 p. 1978.

BISHOP, P. Drainage rearrangement by river capture, beheading and diversion. Progress in Physical Geography ,19, n. 4, p. 449-47. 1995.

CASTRO, L. G.; FERREIRA, F. J. F.; ANGULO, R. J. Modelo gravimétrico-magnético do Gráben de Paranaguá-PR, Brasil. Revista Brasileira de Geofísica São Paulo, v. 26, p. 273-292, 2008 .

COUTINHO, J. M. V. Dyke Swarms of the Paraná Triple Junction, Southern Brazil. Geol. USP, Série científica, v. 8, n.2, p. 28-52. 2008.

COX, R. T. Analysis of drainage-basin symmetry as a rapid technique to identify areas of possible Quaternary tilt block tectonics: as example from the Mississippi Embayment. GEOLOGICAL SOCIETY OF AMÉRICA BULLELIN, v.106, p. 571-581, 1994.

CURY, L. F. Geologia do Terreno Paranaguá. Tese de Doutorado. Instituto de Geosciências da Universidade de São Paulo. São Paulo. 202p. 2009.

DE BLIEUX, C. W. Photogeology in Gulf Coast exploration. Bull. Am. Assoc. Petroleum. Geol. n.33, p. 1251-1259. 1949.
DEFFONTAINES, B \& CHOROWICZ, J. Principles of drainage basin analysis from data: application to the structural analysis of Zaire Basin. Tectonophyzics, v. 3, n.194, p. 237-263. 1991.

ETCHEBEHERE, M. L. C. ; SAAD, A. R. ; PERINOTTO, J. A. J. ; FULFARO, V. J. . Aplicação do Índice "Relação DeclividadeExtensão - RDE" na Bacia do Rio do Peixe (SP) para detecção de deformações neotectônicas. Revista do Instituto de Geociências - USP - Série Científica, São Paulo, v. 4, n.2, p. 43-56. 2004.

ETCHEBEHERE, M. L. C. ; SAAD, A. R. ; SANTONI, G. C. ; CASADO, F.C. ; FULFARO, V. J. . Detecção de Prováveis Deformações Neotectônicas no Vale do Rio do Peixe, Região Ocidental Paulista, Mediante Aplicação de Índices RDE (Relação Declividade - Extensão) em Segmentos de Drenagem. Revista Geociências, v. 25, p. 271-289. 2006.

FRANCO-MAGALHAES, A. O. B. ; HACKSPACHER, P. C. ; SAAD, A. R. Exumação tectônica e reativação de paleolineamentos no Arco de Ponta Grossa: Termocronologia por traços de fissão em apatitas. Revista Brasileira de Geociências, v. 40 , p. 2-13. 2010.

HACK, J. T. Stream-profile analysis and stream-gradient index. Journal Research of the U.S. Geol. Survey, v. 1, n. 4, p. 421429. 1973.

HIRUMA, S. T.; RICCOMINI, C.; MODENESIGAUTTIERI, M.C. Neotectônica no Planalto de Campos do Jordão, SP. São Paulo: Revista Brasileira de Geociências, São Paulo, v. 31, n.3, p. 375-384, 2001.

HOWARD, A. D. Drainage analysis in geologic interpretation: a summation. In: American Association of Petroleum Geologists Bulletin, v. 51, p. 2246-2259. 1967.

KING, L. A geomorfologia do Brasil Oriental. Revista Brasileira de Geografia. n. 18, p. 147-265. 1956.

MAACK, R. Picos do Paraná: A propósito de uma comunicação do Sr. Reinhard Maack. Revista Brasileira de Geografia. Jan/ Mar. p. 137-140. 1942.

MAACK, R. Breves notícias sobre a Geologia dos Estados do Paraná e Santa Catarina. Arquivos de Biologia e Tecnologia, v. 2, Art.7, p. 67-153. 1947.

MAACK, R. A Serra do Mar no Estado do Paraná. Boletim Geográfico. Rio de Janeiro, v.31, n. 229: p. 79-105. 1972.

MARTINEZ, M.; HAYAKAWA, E.; STEVAUX, J. C.; PROFETA, J. D. . SL index as indicator of anomalies in the longitudinal profile of the Pirapó River. Revista Geociências, v. 30 , p. $63-76,2011$.

MELO, M. S.; RICCOMINI, C.; ALMEIDA, F.F.M.; HASUI, Y. Sedimentação e tectônica da Bacia de Resende, RJ. An. Acad. bras. Ci., v. 57, p. 467-479. 1985.

MINEROPAR S. A. Mapa geológico do Estado do Paraná. Folha Curitiba, Escala 1: 250.000. Curitiba-PR. 2005. 
OUCHI, S. Response of alluvial rivers to show active tectonic movement. Bulletin Geological Society of America. Boulder, Co. v. 96, p. 509-517. 1985.

PRÓ-ATLÂNTICA. Atlas da Floresta Atlântica no Paraná. Curitiba: Pró-Atlântica/SEMA Paraná, 104p. 2005.

RICCOMINI, C. O Rift Continental do Sudeste do Brasil. Tese de doutorado. Instituto de Geociências da Universidade de São Paulo. São Paulo. 256p. 1989.

RICCOMINI, C.; COIMBRA, A. M.; SUGUIO, K.; MINHÁLY, P. MATURANA, E. C. Nova unidade litoestratigráfica cenozóica da Bacia de Taubaté, SP: Formação Pindamonhangaba. Bol. IGUSP. v. 9. p. 141-147. 1991.

ROCKWELL, T.K., KELLER, E.A., DEMBROFF, G.R. Quaternary rate of folding of the Ventura Avenue Anticline, western Transverse Ranges, Southern California. Geol. Soc. Am. Bull. n. 100, p. 850-858. 1988.

SABINS JR. F. F. Remote Sensing: Principles and interpretation. San Francisco: Freeman, 464p. 1978.

SALAMUNI E. Tectônica da Bacia Sedimentar de Curitiba (PR). 214f. Tese (Doutoramento em Geociências) Instituto de Geociências e Ciências Exatas, Universidade Estadual PaulistaRio Claro, 1998.

SALAMUNI, E. ; PORTELA FILHO, C. V. . Contribuição à geologia e à morfotectônica da Serra do Mar no Estado do Paraná. In: Seminário 2000 Ensino e Pesquisa do Setor de Ciências da Terra, 2000, Curitiba. CD-ROM.

SALAMUNI, E. Evidências da Neotectônica na Evolução da Serra do Mar no Estado do Paraná. Anais do X Simpósio Nacional de Estudos Tectônicos (X SNET), Curitiba, p. 202204, 2005.

SALAMUNI, E.; FIORI, A. P. . Eventos deformacionais do Neoproterozoico ao Neógeno e a tectônica ressurgente no território paranaense. In: 46 Congresso Brasileiro de Geologia, Santos. Anais do 46 Congresso Brasileiro de Geologia. 2012. São Paulo: Sociedade Brasileira de Geologia.

SALGADO, A. A. R. ; MARENT B. R. ; CHEREM L. F. ; BOURLÉS, D. ; SANTOS, L. J. C. ; BRAUCHER, R ; BARRETOS, H. N. . Denudation and retreat of the Serra do Mar escarpment in southern Brazil derived from in situ-produced ${ }^{10} \mathrm{Be}$ concentration in river sediment. Earth Surface Processes and Landforms (Print), 2013.

SIGA JUNIOR, O; BASEI, M. A. S.; MACHIAVELLI, A. Evolução geotectônica da porção NE de Santa Catarina e SE do Paraná com base em interpretações geocronológicas. Revista Brasileira de Geociências, n. 23. V. 3. P. 215-223. 1993.

SIGA JUNIOR, O. Domínios tectônicos do sudeste do Paraná e nordeste de Santa Catarina: Geocronologia e evolução crustal. Tese de Doutorado. Instituto de Geociências da Universidade de São Paulo. São Paulo, 212 p. 1995.

SILVA, T. P. ; MELLO, C.L . Neotectônica na Região da Zona de Cisalhamento do Rio Paraíba do Sul e Áreas Adjacentes, entre Miguel Pereira (RJ) e Juiz de Fora (MG). In: $10^{\circ}$ Simpósio de Geologia do Sudeste (SGS)., 2007, Diamantina. $10^{\circ}$ Simpósio de Geologia do Sudeste (SGS). 2007.

SOUZA, L. A. P., TESSLER, M. G., GALLI, V. L.. O Gráben de Cananéia. Revista. Brasileira. Geociências, v. 26 n. 3, p.139$150,1996$.

SUMMERFIELD, M. A. Tectonic geomorphologic. Progress in Physical Geography. v. 15, n. 2, p. 193-205. 1991.

VALERIANO, M. M.; ROSSETTI, D. F. TOPODATA: Seleção de coeficientes geoestatísticos para o refinamento unificado de dados SRTM. São José dos Campos: INPE. 2009.

VIGNOL-LELARGE M. L. M.; SOLIANI JR. E.; POUPEAU, G. Datação pelos traços de fissão do Domínio Meridional da Serra do Mar (Arco de Ponta Grossa-Brasil). In: SBG, Congresso Brasileiro de Geologia, Balneário Camboriú, v.38, Anais, p. 379-380. 1994.

ZALÁN, P. V.; WOLFF, S.; ASTOLFI, M. A. M. et al. Bacia do Paraná, in: Raja-Gabaglia, Guilherme Pederneiras e Milani, Edison José (org). Origem e evolução de bacias sedimentares Rio de Janeiro: Ed. Gávea: R. Redisch Prog.Visual Prod. Graf. e Editoração: PETROBRAS. 1990.

ZALÁN, P. V. \& OLIVEIRA, J. A. B. Origem e evolução do Sistema de Rifts Cenozoicos do Sudeste do Brasil. Boletim de Geociências da Petrobras, Rio de Janeiro, v. 13, p. 269-300. 2005. 
